\title{
波浪・潮流による大阪湾底泥の巻き上がり特性 \\ STIRRING-UP OF SOFT SEA BED MATERIAL DUE TO ACTIONS OF WAVES AND CURRENTS IN OSAKA BAY
}

\author{
高山知司 ${ }^{1} \cdot$ 吉岡 洋 $^{2} \cdot$ 田邊義隆 ${ }^{3} \cdot$ 大和 $\quad$ 剛 $^{4}$ \\ Tomotsuka TAKAYAMA, Hiroshi YOSHIOKA, Yoshitaka TANABE, Tsuyoshi YAMATO \\ 1 フエロー工博 京都大学教授 防災研究所海岸海域分野（T611-0011 京都府宇治市五ヶ庄） \\ 2 正会員 理博 京都大学助手 防災研究所海岸海域分野（广611-0011 京都府宇治市五ヶ生） \\ 3 正会員 工修 日本水工設計株式会社 東京支社（T104-0054 東京都中央区勝ちどき 3-12-1） \\ 4 京都大学大学院 工学研究科（T611-0011 京都府宇治市五ヶ生）
}

\begin{abstract}
Stirring-up of soft sea bed material in Osaka Bay were investigated through field observations and hydraulic experiments. Field observations were carried out at the point of $14 \mathrm{~m}$-deep and $15 \mathrm{~km}$ apart from Kansai International Airport. The bed material size at the filed is $0.01 \mathrm{~mm}$ in mean diameter. Echo Intensity data of ADCP were used to detect the stirring-up of bottom material induced by wave and current. The threshold value of current velocity for stirring-up has been estimated to be about $20-\mathrm{cm} / \mathrm{s}$. The different properties of stirring-up between fine sand and silt were has experimentally been checked in wave oscillatory flow in the wave channel. In less than $10 \mathrm{~cm} / \mathrm{s}$ flow condition, the fine sand was stirried-up easily with ripple formation. The silt needs faster current for stirring-up because it could not move individually.
\end{abstract}

Key Word: Stirring up, Siltasion, ADCP

\section{1. 緒睔}

底泥の巻き上がりは, 東南アジア沿岸, 有明海等で航 路や泊地の埋没化 (シルテーション) や, 海底に堆積し た栄養塩の再浮遊による污染域の拡大等の問題を引き起 こしている. また自然干潟の保存や人工干潟の創造に対 しても，巻き上がり現象が関与している. 波浪, 潮流が 底泥を巻き上げる条件を把握することができれば, 海域 開発の円滑化, 海底地形の積極的な利用ならびに環境保 全に貢献できるものと考える.

大阪湾東部は潮流が弱弱い停滞性海域である. そこへ淀 川をはじめとする河川を通して, 大量の栄養塩が陸地か ら供給され、大量の負荷物質として堆積してシルト質と なっている。そのため, 他の砂質海域の底質とはかなり 異なった性状を示すものと思われる.

また，年々拡大してゆく湾内の埋め立てや防波堤設置 によりこの流れ場が歴史的に変化してきて, 従来の巻き 上がり基準では対応できないことも考えられる.

そこで本研究は, 大阪湾の底泥を対象として, 巻き上 がりの実態を把握する水理実験, ならびに現地観測デー 夕より波浪, 潮流や気象変化, その他の環境条件を考慮 した解析を行い, 海底の巻き上がり特性の把握と巻き上 がり基準を設定することを目的とする.

\section{2. 锚測データ}

\section{（1）観測方法}

大阪湾岸和田沖にあるコンパスロケーターにおいて, $\mathrm{ADCP}$, 濁度計, その他の水質計を用いて観測して得た データと関西国際空港 MT 局で観測されたデー夕を用い た ${ }^{1)}$. 観測期間は, 1997 年 9 月 14 日〜 10 月 2 日, 1998 年 5 月 28 日〜8 月 24 日である. 観測地点の水深恃約 $14 \mathrm{~m}$ であり, 海底は平坦な地形である (図-1).

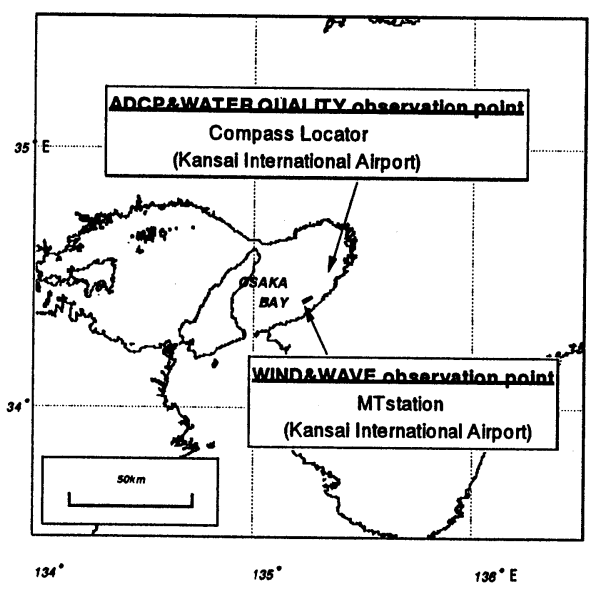

図-1 観測地点 
（2） ADCP (超音波ドップラー流速分布計）

周波数は $1200 \mathrm{kHz}$ である. 水深約 $14 \mathrm{~m}$ の海底に設置し て, 直上の水域を 30 層に分けて, 各層の後方散乱強度 (ECHO (1) 〜 (30)) と流速の水平 2 方向の成分を観測する. 底泥が巻き上がると海底に最も近い $\mathrm{ECHO}(30)$ およびそ の次の $\mathrm{ECHO}$ (29)に高い值が出現すると期待される。 $\mathrm{ADCP}$ は 1997 年 9 月 14 日〜 10 月 2 日, 1998 年 5 月 28 日〜7月 15 日ではコンパスロケーターの北側, 7 月 15 日〜8月 24 日では南西側に設置している. 記録デー夕は, 1997 年は 5 分間, 1998 年は 10 分間の平均値をとってお り,流速データには波による往復流は取り除かれている.

\section{（3）水質計測装置}

濁度計は光透過型のものを使用した. 海面から $1 \mathrm{~m}$ (上 首), 海底から $7 \mathrm{~m}$ (中層), $1 \mathrm{~m}$ (底首) のところに設置 し, その位置での濁度を 10 分おきに観測, 記録した. 他 の水質計も濁度計と同位置に設置し，その位置の水温， 塩分, DO (溶存酸素量) を記録した（図-2）.

\section{（4）記録内藏型波向計測装置 (WAVEHUNTER)}

海底に WAVEHUNTER を設置した. それは, 水圧と水 平2万向の流速を計測することにより,その地点の水位, 波高（最大波高, $1 / 3$ 有義波高, $1 / 10$ 有義波高及び平均 波高), 周期, 波向, 流向流速を 1 時間おきに記録する. 波向は主波向と平均波向が算出される. なお観測期間は

\section{3. 水理実験}

\section{（1）実験方法}

図-3 に示すように長さ $26.4 \mathrm{~m}$, 幅 $0.70 \mathrm{~m}$, 高さ $0.70 \mathrm{~m}$, 両面ガラス張りの 2 次元造波水槽の中央部に長さ $1 \mathrm{~m}$, 幅 $0.40 \mathrm{~m}$, 高さ $0.30 \mathrm{~m}$ のアクリル製の凹部を設け，ここに大 阪湾の底泥の試料を満たした。水槽後部には $1 / 10$ の勾配 をつけて反射波の影響を軽減させた. 凹部の上部には 2 台の容量式波高計を設置した. 凹部の試料の中に 3 個の 圧力計を表面下 $3 \mathrm{~cm}, 7.5 \mathrm{~cm}, 10 \mathrm{~cm}$ の深さへ設置し, 波 作用下の底質内の圧力変化を測定した.

本実験で用いた試料は，関西国際空港 MT 局付近で採 取された底泥で, 黒色のシルト質（平均粒径は $0.01 \mathrm{~mm}$ 程度 ${ }^{2)}$ ) であった. ダイバーが潜水して海底表面に堆積 したものを掬い取り, 水中で容器に入れて密封して採集 した. 底泥との比較実験として, 豊浦標準砂（中央粒径 值 $0.17 \mathrm{~mm}$ ）を用いた実験も行った.

実験は，水槽凹部を標準砂で満たした場合と，凹部の $7.5 \mathrm{~cm}$ の深さまでは砂を入れ，残りを底泥で満たした場 合について行った. 水深は, 標準砂利用時 $30 \mathrm{~cm}$, 底泥利 用時は $30 \mathrm{~cm}$ と $20 \mathrm{~cm}$ である. 巻きあがりの判定は目視に て行なった. また水槽凹部真横からビデオ撮影を行い, 波作用下の水中の様子を記録した. 1998 年 6 月 10 日〜 7 30 日である.

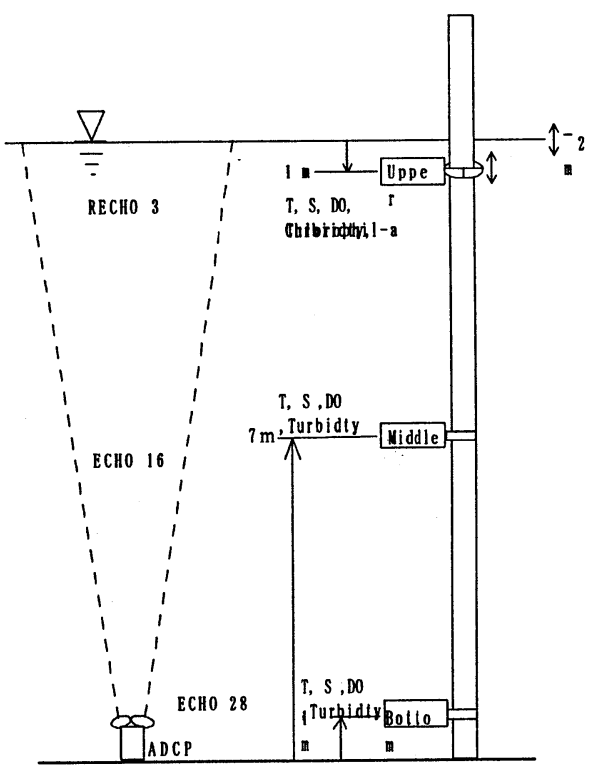

図-2＼cjkstart観測機器設置図

\section{（5） 関西国際空港 MT 局データ}

WAVEHUNTER データとの比較や欠測した時期の值 を補間するために，コンパスロケーターの南西約 $15 \mathrm{~km}$ に位置している (図-1), 関西国際空港 MT 局の波浪デ 一夕, 有義波高および周期, 波向, 潮位の 1 時間毎のデ 一タを活用した.

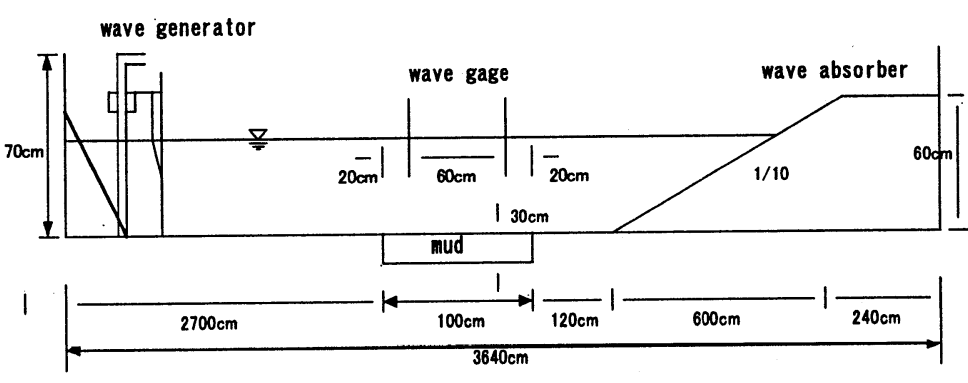

図-3 実験装置
（2）実験結果

\section{a) 豊浦標準砂の挙動}

表面を平滑にしてから水槽に水を入れ，波を起こした. はじめの弱い波作用下では，表面は変化せず，平滑な状 態を維持していた. 造波装置の出力を上げ, 徐々に大き な波へ変化させてゆくと, やがて表面上にかすかな線状 の峰が，次々と見え始め、やがて小さな山型を形成して ゆき, 前進し始めた. 峰の間隔が 5 6cm 程になると, 水槽に直角な, 直線状のリップル（砂漣）を形作り, 峰 の前進は止まった.このときの波高は $9 \mathrm{~cm}$, 周期は 1 秒, 往復流の速さは $7.4 \mathrm{~cm} / \mathrm{s}$ であった. 形成される山の高さ, 谷の深さはそれ以降，あまり変わることがなかった. 砂 がリップルの峰を超えてゆくときと往復流が前進から後 退, 或いは後退から前進するときに巻き上がりが顕著で あった. 特に往復流の方向が切り替わる時の浮遊粒子は, 一斉に方向を鈶直方向に変えることが観察された. 


\section{b）底泥の挙動}

底泥が巻き上がりはじめるときの流速を求めるため, 造波装置の出力を上げたり, 造波周期を変えることによ って, 往復流の水粒子速度を上げていった. しかし, 造 波装置の出力が河かったため, 底質の表面付近で生じた 速度は高々9〜 $10 \mathrm{~cm} / \mathrm{s}$ 程度であり, 明確な巻き上がりに は至らなかった. しかし, 微小粒子が小さい水粒子速度 で巻き上がる場合が 3 例あったので，それを説明する.

\section{・底質表面を練り返したとき}

底泥を満たして波を起こすとまず，微小粒子のまい上 がりが認められる. しかし，造波を続けるうちに底質表 面の微粒砂がなくなると, より大きな波を与えても巻き 上がりが生じない，そこで，泥質をよく掘り起こした後 で表面を平滑にして, 波を作用させると, 瞬時に水中が うすく濁った. それは底質の泥粒子が巻き上がったので はなく, 泥首の表面の微細粒子がほぼ鈶直に上ってゆく のである. それもしばらく波を受けると表面の微細粒子 は出尽くし, また, 濁りも拡散して, 巻き上がりは止ま ってしまった.

\section{・ 長周期の波を作用させたとき}

できるだけ大きな海底上の往復流速を得るために, 4 秒の周期をもつ波を起こして, 底泥上に作用させると, 砂の時ほど規則正しい配列をしてはいないが，うろこ状 の, 大きさ $1 \mathrm{~cm}$ ほどの小さなリップルが多数観察された. リップルが生じた時, 表面の落ち込んだ部分に, 表面部 分からはがれた, やや大きめの泥粒子が集積していた. この粒子は波の運動とともに落ち込みを出たり入ったり するが，時には渦を巻きながら水中へ放散してゆく．ま た長周期時の波は形が崩れ，倍調波が生じてサインカー ブを描いていなかった. そのためか浮遊した泥粒子が波 とは逆の方向に漂っていくことがあった.

\section{- 底質全体が微小振動する時}

波作用下において, 容器内の底質全体がわずかにでは あるが前後に振動するときがあった. 微小振動が起こっ た状態では瞬間的に巻き上がりが生じていた.しかし， これは水槽凹部の境界で隙間が生じた所で小さなずれが 起こっている為である. この状態は底泥を練り返した時 に生じたので, 含水比等底質内の水の量に影響している かもしれない。

以上実験によって, 泥層表面にはたらく流速が $10 \mathrm{~cm} / \mathrm{s}$ 程度ならば巻き上がりは生じず, 明らかな巻き上がり現 象をみとめるにはさらに大きな流速が必要であることが わかった. また, 底泥の状態, 或いは底泥に作用する波 の状態によって, 巻き上がり方にも違いが生じることが わかった. しかし実験は砂層の上に泥層を設けたこと, 海水ではなく真水を利用したこと, 水深十数 $\mathrm{m}$ から採取 した底泥を $20 \sim 30 \mathrm{~cm}$ という浅い水深で行ったため水圧 が著しく小さいことなど, 採取地点の底泥におかれた状 況と異なる点があった.

\section{4. 現地観測結果}

\section{（1）時系列データの整理}

対象期間を 14 に区分してぞれぞれ観測データの時系 列変化を示した. 区分期間の 1 つである, 図-4について 説明する. 図中の一番上は水深約 $8 \mathrm{~m}$ から海底までの $\mathrm{ADCP}$ 後方散乱強度(以後, 反射強度と呼ぶ)のコンタグ ラフ, 2 番目は海底付近の流速べクトル, 3 番目は一定水 深ごとの反射強度, 4 番目図は海底付近の流速絶対值, 5 番目は濁度, 6 番目は波高, 7 番目は周期、 8 番目は潮位, 9 番目は相対水深 (水深を波長で割ったもの), 10 番目は 海底の波浪往復流の振幅, 11 番目は $\mathrm{ADCP}$ が測定した水 平成分の流速から算出した潮流の流向,12 番目は WAVEHUNTER が算出した主波向,13 番目は ADCP が測 定した流速と往復流による水粒子速度との和 $u+C V, 14$ 番目は溶存酸素量（DO）である.

相対水深は波長によって変化して, これが 0.5 を下回 ると波が海底付近に与える影響は無視できる.

波浪往復流の振幅 $u$ の時系列デ一夕は, 波が微小振幅 波であると仮定したときの, 浅海波の水粒子速度の式

$$
u=\frac{H}{2} \cdot \frac{g T}{L} \cdot \frac{\cosh \{k(h+z)\}}{\cosh (k h)} \cos (k x-\omega t)
$$

に最大波高，最大波高時の周期を代入して算出した. $u+C V$ はWAVEHUNTER か観測された期間 (1998 年 6 月 11 日〜 7 31 日）においては, 潮流と最大波高 - 周 期から推算された往復流とのベクトル和, 観測されなか つた期間（1997年, 1998 年 5 月 28 日〜 6 月 10 日と 8 月 1 日 8 月 24 日） は潮流と最大波高・周期から推算され た往復流との単純和を示す.

\section{（2）時系列データに見る巻き上がり状態}

巻き上がりがどのような環境条件で生じているかを具 体的に把握するために, 代表的な巻き上がり事例を, 14 に区分した時系列データを順に追って調べた. その結果, 底泥の巻き上がりと波浪, 潮流に関するデータとの関係 についてまとめると以下のようになった.

- 潮流の流速や波高の值から判断して, 巻き上がり が生じていると推定されるのは, ECHO(29)が70dB を超えたときである. しかし, 70dB を超えないも のについても, ECHO(29)のデータに急激な上昇傾 向がある場合, ECHO(30)において上昇が認められ る場合は小規模な巻き上がりが生じているといえ る. 巻き上がり現象が顕著に見られるのは, 最大波 高 $H \max$ が 70cm を超えたころからであり, 潮流が $10 \mathrm{~cm} / \mathrm{s}$ 以下であっても, 波高が高ければそれに伴い ECHO の值は上昇する. 


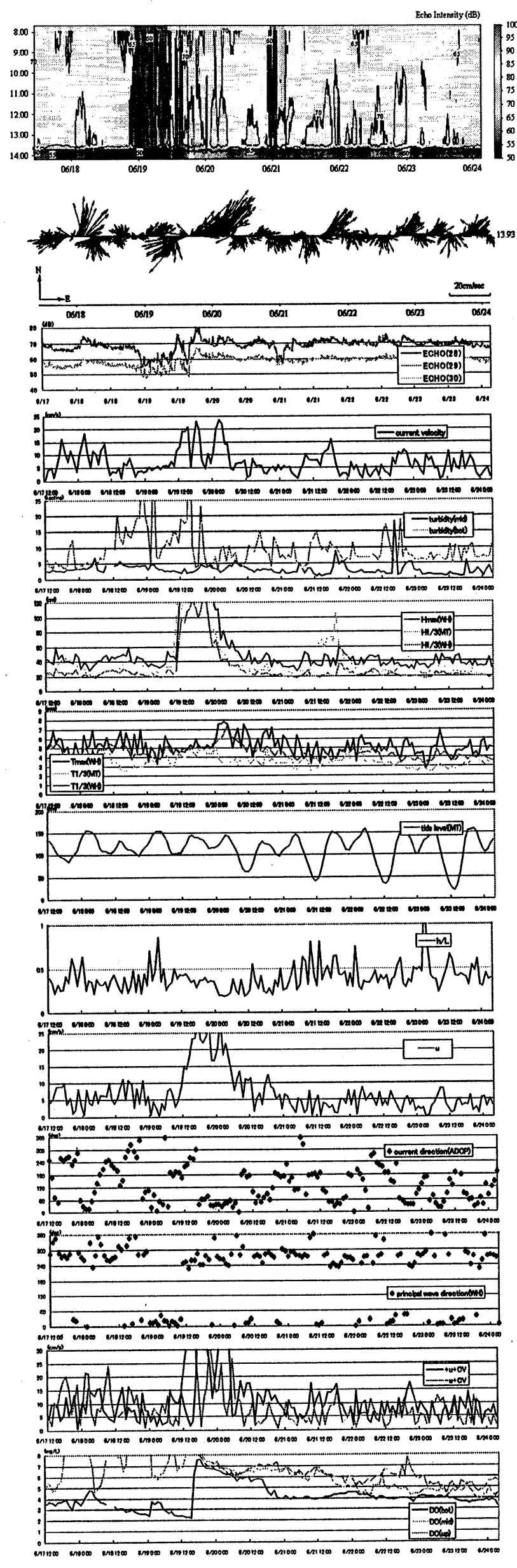

図-4 時系列データ
- 波高が小さくても潮流の速度が $20 \mathrm{~cm} / \mathrm{s}$ 以上の大 きい時に, 巻き上がりが起こる場合があり,それは 満潮の北流最大時や干潮の南流最大時に生じてい る.

大規模な巻き上がりが生じていると考えられる 時期において, 上層, 中層, 底層の DO の值が接近 している場合がある. 通常 DO は, 植物プランクト ンの光合成の関係から, 光が届く浅い層ほど高い值 を示すにも関わらず, このように一定の值を示す時 期があった. これは水中の上下混合が激しいことを 示しているものと考えられ, 巻き上がりが発生しや すい状態を表していると言える.

\section{5. 考察}

（1）潮流と往復流との単純和，ベクトル和

ADCP から得られた海底付近の潮流の流速と, 計算に よって求めた往復流の水粒子速度がいずれも $5 \sim 25 \mathrm{~cm} / \mathrm{s}$ と同じ位のオーダーであった. 潮流の流向, 波向（図-4 上から 11,12 番目) を見ると変化が大きく, 特に流向は 潮汐の運動に伴い変わっている. よって潮流と波浪によ る往復流の 2 次元的な運動を包括的に捉えて巻き上がり を検討する必要があると考え，両速度のべクトルの和を とった. なお, ベクトルのなす角度は, ADCP データの 水平 2 方向成分から算定した潮流の向き, WAVEHUNTER の記録した主波向から求める. 往復流の 水平成分は波の進行方向に前進, 後退を繰り返すこと, しかも水粒子速度の最大時を考慮して式(1)の $\cos (k x-\omega$ $t)=1,-1$ それぞれについてのベクトル和を求めた. さら に, 振動流が同時刻で前進, 後退したときのベクトル和 のうち大きいものをその時刻の代表する流速（以後、

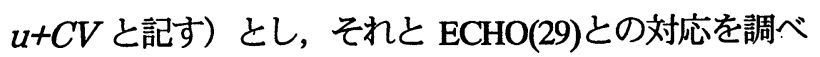
た (図-5)。その結果, 流速が大きいにも関わらず反射 強度が大きな值を示さなかったり, 或いは小さな流速で 大きな反射強度を示したりした. この原因として考えら れるものを列挙すると以上のようになる.

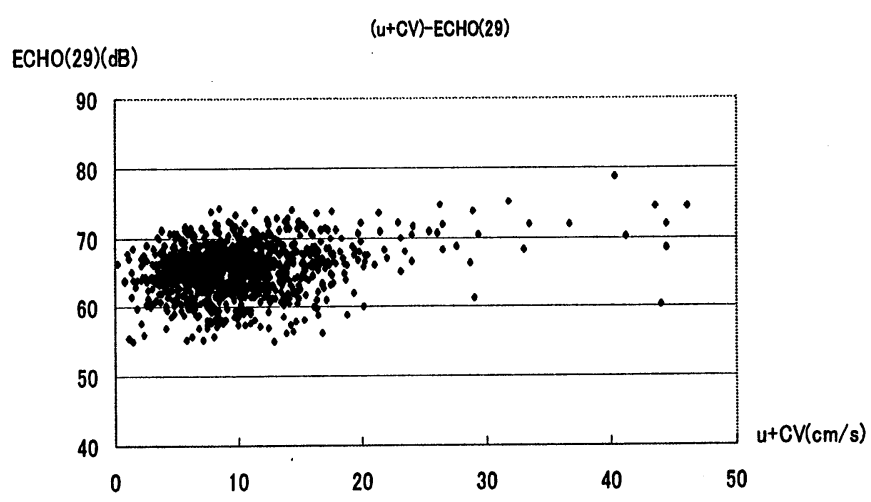

図-5 u+CV と ECHO (29)の相関(98 年) 
・ 波浪, 潮流が引き起こした巻き上がり現象ではなく, プランクトンや気泡といった散乱体による超音波 反射の可能性

プランクトンはその種類, 形, 大きさで様々な反 射強度をとることが報告されており, 海水中では場 所を問わず生息しているので, ADCP の発した超音 波によって検知されることもあり得る.

・ 最大波高 $T \max (\mathrm{WH})$ の考慮によるもの

往復流による水粒子速度の式(1)には，最大波高 $H \max (\mathrm{WH})$ と最大波高時の周期 $T \max (\mathrm{WH})$ を代入 している. 海底の巻き上がりにおいて, 有義波高の ような平均值を適用するより, その時間における最 大の波高を用いた方が海底への影響をより忠実に 表現できると考えたからである. しかし大半は $H \max (\mathrm{WH})$ より小さな波が起きているはずである から,ベクトル和が実際より過大に評価されている ことが考えられる.

・巻き上がった後の底泥が海底に沈下せずにそのま ま漂っている.

流速が大きい時に巻き上がった底泥が, 流速が減 少したにも関わらず, 浮遊し続けるために大きな反 射強度を示した.

以下では 3 番目の可能性について検証をしてゆく.
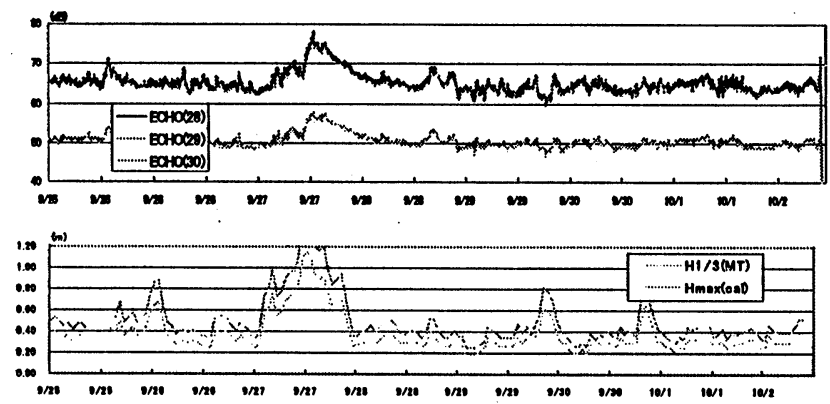

图-6 ECHO(29) と波高の時系列デー 夕(97年 9 月 25 日〜 10 月 2 日)

\section{（2）巻き上がりの浮遊時間を考慮}

図-6 の ECHO(29)と波高データの挙動を比較する. 両 者は9 月 27 日のはじめから増大傾向を示し, 正午同時期 に, ECHO(29)は76dB, $H 1 / 3(\mathrm{MT})$ は $117 \mathrm{~cm}$ のピーク值を 示した. しかし, その後波高は減衰し, 同日終わりに $27 \mathrm{~cm}$ まで下がるのに対して, ECHO(29)は緩やかに減少し増大 前の值に戻るのは 28 日の午後であった. 波の高揚時には 海底で往復流の影響か溞いと思われ、それに伴い巻き上 がりも生じていると推測される. しかし波が減衰した後 もなお ECHO(29)が高い值を維持し続けているのは，巻 き上がった泥粒子が海底に再び沈下するまでに時間を要 するため, それがECHO(29)の值に反映すると思われる.
流速のベクトル和と ECHO(29)との相関（図-5）におい て, ベクトル和が小さい值から, ECHO(29)が70dB 以上 の高い值をとるのは，この巻き上がりの浮遊時の影響が あると考え，以下の検証を行った.

反射強度が $70 \mathrm{~dB}$ 以上を示すものを巻き上がりが生じ ていると考え, $\mathrm{ECHO}(29)$ の時系列データから, 70dB 以 上を示す時期を抽出する. それらの時期で, ECHO(29) がピークを示したときから落ち込むまでの時間を, 底泥 が浮遊している時間と特定した. その時間のデータを除 去してからべクトル和, $\mathrm{ECHO}(29)$ の相関をとった(図-7). 図は除去後のデータを波高, 潮流の流速, 往復流速の大 きさ別に区分したものである. ECHO(29)が落ち込む值は 時系列データのグラフの挙動, 数値を吟味した上で判断 したため, 明確な值は定めていない.

1997 年のデータ, 1998 年 5 月 28 日〜 6 月 10 日と 8 月 1 日〜8 月 24 日のデータにおいては, WAVEHUNTER に よる観測が行われていないため主波向が欠けている. そ こで水粒子速度 $u$ と ADCP が記録した流速との和と, $\mathrm{ECHO}(29)$ との相関をとった. そして, 1998 年 WAVEHUNTER データによるものと同様に, ECHO(29) の值のピーク後から落ち込むまでの時間のデータを除去 して，相関をとった（図-8:1997 年データ，図-9:1998 年 データ). その結果, 図-7では ECHO(29)が増大する傾向 が、 $20 \mathrm{~cm} / \mathrm{s}$ を超えてはじめて見られ，図-8，図-9 では， $30 \mathrm{~cm} / \mathrm{s}$ を超えてはじめて見られた。

図-8, 図-9 は往復流と潮流のベクトルの合成ではなく 和をとつたため, 図ではばらつきが右にシフトしている と思われる. よって, 潮流と往復流のベクトル和を考慮 した場合から, 大阪湾の底泥が巻き上がりはじめる時の 值は，およそ $20 \mathrm{~cm} / \mathrm{s}$ であると推定した.

先に求めた潮流と往復流のベクトル和は式(1)の $\cos (k x-\sigma t)$ を $1,-1$ として求めた. しかしこれは最大值, 最小值である. 往復流は時間に伴い絶えず変化し続ける 点において, 潮流とその性格を異にする. 潮流は長期的 に見れば，その速度や向きを変化させるが，短期間で考 えると一定である. これら往復流の周期的な速度変化を する流れと，潮流の一様な流れを巻き上がりに対して同 等に扱うことの妥当性を検討する.

図-7，図-8，図-9 は，波高 $H \max$ は $60 \mathrm{~cm}$, 潮流の流 速 $C V$ は $10 \mathrm{~cm} / \mathrm{s}$ と $20 \mathrm{~cm} / \mathrm{s}$, 往復流の流速 $u$ は $10 \mathrm{~cm} / \mathrm{s}$ を それぞれ基準として，その值より大か小かにより区分し たときの $u+C V$ と ECHO(29)の相関をとったものである. それによると, $u+C V$ の值が概ね

- $\quad H \max$ 小, $C V$ 小, $u$ 小

- $H \max$ 小, $C V$ 中 $(10 \sim 20 \mathrm{~cm} / \mathrm{s})$ 或いは $H$ max 小, $u$ 大

- $H \max$ 大, $\mathrm{CV}$ 中

- $H \max$ 大, $u$ 大

の順に大きくなっている. いずれの図も, $u+C V$ の中速 域 $(10 \mathrm{~cm} / \mathrm{s}<u+C V<20 \mathrm{~cm} / \mathrm{s})$ では $H \max (\mathrm{WH})$ が $60 \mathrm{~cm}$ 末満 
で潮流の流速が 10〜20 cm/s の状態が頻繁に生じている が，大部分は反射強度が 70dB を下回っている.

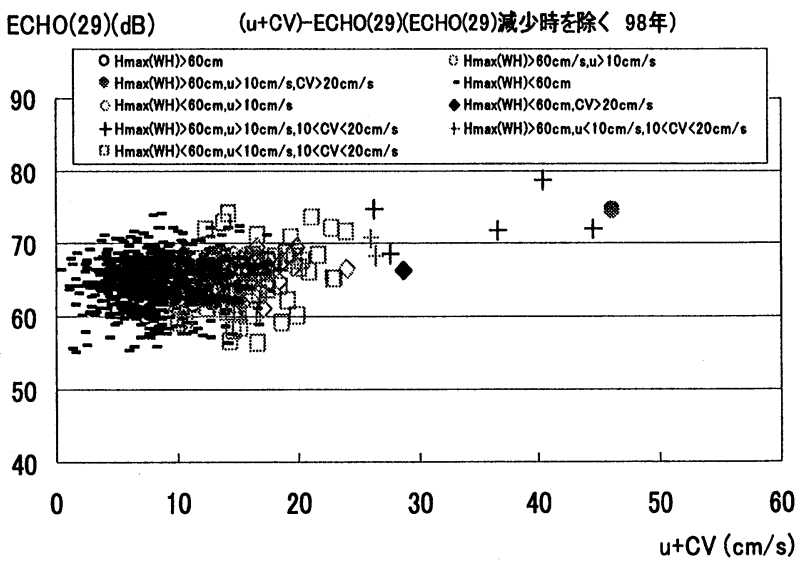

図-7 浮遊時間除去後の $u+C V$ とECHO(29)の相関(98 年)

$E C H O(29)(d B)(u+C V($ 単純和 $))-E C H O(29)(E C H O(29)$ 娍少時を除く 97年)

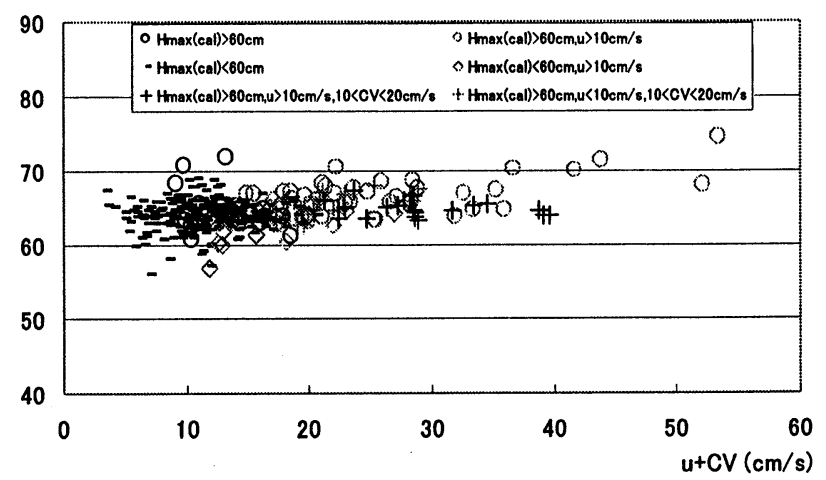

図-8 浮遊時間除去後の u+CV と ECHO (29)の 相関(97 年 WH 不測定)

$(u+C V($ 単純和))-ECHO(29)(ECHO(29)娍少時を除く 98年(WH測定せず)) ECHO(29) (dB)

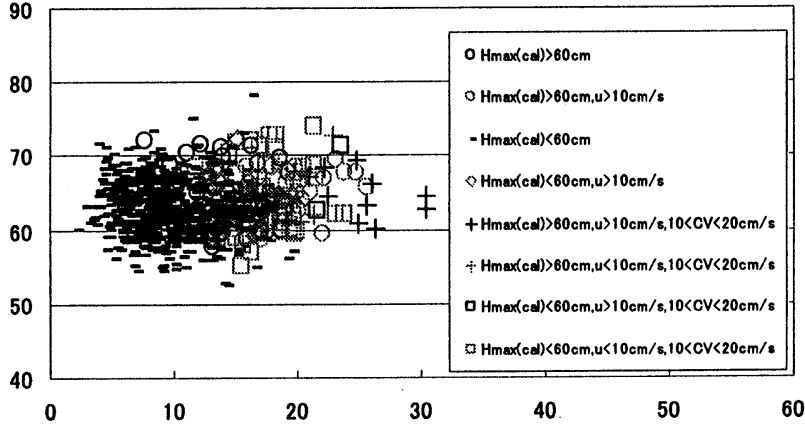

図-9 浮遊時間除去後の u+CV と ECHO(29)の 相関(98 年 WH 不測定)

また，図-8，図-9 では，Hmax が 60cm より大（図中の 丸印）であれば, $u+C V か ゙ ~ 10 \mathrm{~cm} / \mathrm{s}$ 以下の小さいときでも
高反射強度を示している.

よって, 巻き上がりか起こるのは波による往復流の影 響があるときである. 潮流のみ作用する海底では, 流速 が $20 \mathrm{~cm} / \mathrm{s}$ 以下では巻き上がりは起こらないと思われる.

\section{（3）潮流と往復流の性質を考察する}

潮流と往復流の合成によって, 反射強度との間に高い 相関が得られたことや， $20 \mathrm{~cm} / \mathrm{s}$ を超える流速をもつとき に大きな反射強度を示していることを考慮すると，巻き 上がりを引き起こす要因は主に波の運動によるものであ り，潮流はその運動によって起きた巻き上がりを，助長 する形で影響を与えていると考える. また波作用下では 往復流が $10 \mathrm{~cm} / \mathrm{s}$ 程度の速度でも巻き上がりが起こり得 ることから流速以外の波の特性が起因している可能性が ある. たとえば, 往復流の周期的な変化や強弱により底 泥表面の粒子間に変化が起きることが考えられる.

\section{6. 結圇}

本研究は, 実験によって巻き上がり時に伴う現象や巻 き上がりやすさの検討を行った. また, 1997年9月と1998 年 6, 7,8 月の波浪と潮流に関わる観測データから, 巻 き上がり時例の抽出と巻き上がり基準の設定を行った. 以上のことをまとめて, 本研究で得られた結果に対して 結論を述べる.

- 底泥の巻き上がりの指標として ADCP の測定する 後方散乱強度が利用できる. 巻き上がりを示すのは海底 近傍での值が 70dB を超えたときに顕著である.

- 実験によって, 往復流による流速が $10 \mathrm{~cm} / \mathrm{s}$ 程度な らば, 底泥の巻き上がりが起こらないことが確認された。 また，潮流の流速べクトルと波による往復流のベクトル との合成成分之, 後方散乱強度の関係から, 大阪湾の底 泥が巻き上がりはじめるのは，合成べクトルがおおよそ $20 \mathrm{~cm} / \mathrm{s}$ に達する時であると推定した.

- 波浪と潮流を比べると, 底泥の巻き上がりは波浪に よるところが大きく, 潮流は波浪の運動を助長している.

\section{碀辞}

貴重な観測資料を提供していただいた関西国際空港株 式会社に謝意を表します。

\section{㝐考文献}

1）吉岡洋 - 高山知司 - 田邊義隆 - 加藤久晶(1999)：A D C P による沿岸水質の長期モニタリング, 海岸工 学論文集, 第 46 巻, pp. 1301-1305

2）白石修章・飯島眞治・永野国松・中辻啓二(2000)： 関西国際空港沖における潮流と波による底泥の巻き 上け現象, 海岸工学論文集, 第 47 巻, pp. 1076-1080 